\title{
Nomenclatural and Taxonomic Novelties in Senecio ser. Corymbosi (Asteraceae, Senecioneae) from Southern South America
}

Author(s): Mariana Gabriela López, Arturo Federico Wulff, Lidia Poggio, and Cecilia Carmen Xifreda

Source: Novon: A Journal for Botanical Nomenclature, 20(1):63-67. 2010.

Published By: Missouri Botanical Garden

DOI: http://dx.doi.org/10.3417/2008050

URL: http://www.bioone.org/doi/full/10.3417/2008050

BioOne (www.bioone.org) is a nonprofit, online aggregation of core research in the biological, ecological, and environmental sciences. BioOne provides a sustainable online platform for over 170 journals and books published by nonprofit societies, associations, museums, institutions, and presses.

Your use of this PDF, the BioOne Web site, and all posted and associated content indicates your acceptance of BioOne's Terms of Use, available at www.bioone.org/ page/terms_of_use.

Usage of BioOne content is strictly limited to personal, educational, and noncommercial use. Commercial inquiries or rights and permissions requests should be directed to the individual publisher as copyright holder. 


\title{
Nomenclatural and Taxonomic Novelties in Senecio ser. Corymbosi (Asteraceae, Senecioneae) from Southern South America
}

\author{
Mariana Gabriela López, Arturo Federico Wulff, and Lidia Poggio
}

Laboratorio de Citogenética y Evolución, Facultad de Ciencias Exactas y Naturales, Universidad de Buenos Aires, Ciudad Universitaria, Pabellón 2, $4^{\circ}$ piso, Int. Güiraldes 2620, 1428 Buenos Aires, Argentina; Consejo Nacional de Investigaciones Científicas y Técnicas (CONICET), Avda. Rivadavia 1917, CP C1033AAJ, Ciudad de Buenos Aires, Argentina. magalo@ege.fcen.uba.ar; artulf@ege.fcen.uba.ar; poggiocitoevol@hotmail.com

\section{Cecilia Carmen Xifreda}

Comisión de Investigaciones Científicas de la Provincia de Buenos Aires (CIC-PBA), Laboratorio de Etnobotánica y Botánica Aplicada, Facultad de Ciencias Naturales y Museo, Universidad Nacional de La Plata, calle 64 N³, 1900 La Plata, Argentina. cxifreda@fcnym.unlp.edu.ar

Abstract. The new name, subseries Alcabrerae M. G. López, A. F. Wulff \& Xifreda for Senecio L. ser. Corymbosi (Cabrera) Cabrera, is here proposed to replace Senecio subsect. Amplectentes Cabrera. Although the name Amplectentes was published at different subgeneric ranks within the genus Senecio (Asteraceae, Senecioneae), the use of the same epithet is considered homonymy according to the International Code of Botanical Nomenclature, Article 53.4 and Article 21, Note 1. Additionally, S. saucensis Cabrera, one of the five species belonging to Senecio subser. Alcabrerae, is synonymized with S. toroanus Cabrera, formerly assigned to Senecio ser. Hualtatini DC., and $S$. toroanus is transferred to subseries Alcabrerae. The micromorphology of the cypselae for both species is provided, in support of the synonymy.

Resumen. El nuevo nombre para la subseries Alcabrerae M. G. López, A. F. Wulff \& Xifreda de Senecio L. ser. Corymbosi (Cabrera) Cabrera se propone aquí en reemplazo de Senecio subsect. Amplectentes Cabrera. A pesar de que el mismo nombre Amplectentes fue publicado en rangos subgenéricos diferentes dentro del género Senecio (Asteraceae, Senecioneae), el uso del mismo epíteto es considerado homonimia según el Código Internacional de Nomenclatura Botánica, Artículo 53.4 y Artículo 21, Nota 1. Además, S. saucensis Cabrera, una de las cinco especies pertenecientes a Senecio subser. Alcabrerae se sinonimiza aquí con $S$. toroanus Cabrera, originalmente tratada bajo Senecio ser. Hualtatini DC., y S. toroanus es aquí transferida a subser. Alcabrerae. Se aporta la micromorfología de las cipselas de ambas especies, reforzando la sinonimización.
Key words: Argentina, Asteraceae, Chile, Senecio, ser. Corymbosi, subser. Amplectentes.

Multidisciplinary studies on Asteraceae have been ongoing for several years on taxa from southern South America, mainly of Argentine origin. New research focusing on Senecio L. in the Senecioneae (López, 2008) has revealed the nomenclatural illegitimacy and taxonomic synonymy of representatives within Senecio ser. Corymbosi (Cabrera) Cabrera (Cabrera, 1985; Cabrera et al., 1999). The results presented here include nomenclatural and taxonomic novelties at the subserial and specific level within Senecio ser. Corymbosi.

A New Name for Senecio subser. Amplectentes within Series Corymbosi

The epithet Amplectentes denominated an infrageneric rank in the genus Senecio and was first used by Greenman (1902) to delimit a distinctive group of species with stems erect or ascending and leafy to the inflorescences, pubescence usually of long jointed hairs, amplexicaul stem leaves, and calyculate involucre. The name was validated by its description in the key (Greenman, 1902: 18). The epithet Amplectentes was published by Greenman at the rank of section and applied to 29 Senecio species from the United States and Mexico. The type species for the section was not designated by the author; however, in accordance with Article 22.6 of the International Code of Botanical Nomenclature (ICBN; McNeill et al., 2006), S. amplectens A. Gray (1862) is the implicit type, as the name of the section clearly derives from 
the epithet of one species assigned to it. Later, Greenman (1915: 577) used the name Amplectentes again in a synopsis of the subgenera and sections of Senecio at the rank of section, in a monograph of the North and Central American species. Only 10 of 29 species considered by Greenman are currently accepted (Barkley, 2006). On the other hand, Cabrera (1949) used the same name Amplectentes within the genus Senecio, attributing this to himself, for one of seven subsectional groups pertaining to section Corymbocephalus Cabrera. This name was later reduced to the rank of subseries as subseries Amplectentes (Cabrera) Cabrera \& S. E. Freire (Cabrera et al., 1999) affiliated with the series Corymbosi [ = section Corymbosi Cabrera (Cabrera, 1939), with this name found to have priority over section Corymbocephalus (Cabrera, 1949)].

Additionally, the name Amplectentes was ambiguously cited in the botanical literature, sensu both Greenman (1902, 1915) and Cabrera (1949). Among others, Ornduff et al. (1967: 217, 210) postulated basic chromosome numbers for sections of Senecio in North America and included section Amplectentes Greenman with a base number of 20 ; today $x=5$ is the accepted basic chromosome number for the genus (López et al., 2005, 2008). A different taxonomic view was followed by Barkley (1985: 216-217), who assigned some species previously included under section Amplectentes sensu Greenman to his informal group Herbacei and subgroups Triangulares and Lugentes. Section Amplectentes was later recognized separately again as a "group" (Barkley, 2006: 544, 546) and included 10 species. Jeffrey (1988: 85, 86) annotated both authorities differently as "sect. Corymbosi Cabr. subsect. Amplectentes Cabr." as "perennial leafy-stemmed herbs or subshrubs; upper leaves semiamplexicaul," and "sect. Amplectentes Greenm." as "perennial subscapigerous herbs; upper semiamplexicaul," recognizing Barkley's Triangulares and Lugentes as separate informal groups.

The infrageneric name Amplectentes Greenman (Greenman, 1902) has priority over Amplectentes Cabrera (Cabrera, 1949). Despite the fact that the same name was published at two different ranks (sectional and subsection/subseries, respectively), they are considered homonyms under the ICBN (McNeill et al., 2006: Art. 53.4, Art. 21, Note 1). Consequently, a replacement name is proposed here for subseries Amplectentes within Senecio ser. Corymbosi. This series was previously published at the level of section, as has been previously noted.

Senecio L. ser. Corymbosi (Cabrera) Cabrera, Darwiniana 26: 157. 1985. Basionym: Senecio sect. Corymbosi Cabrera, Lilloa 5: 71. 1939. TYPE: Senecio brasiliensis (Spreng.) Less.

Senecio L. subser. Alcabrerae M. G. López, A. F. Wulff \& Xifreda, nom. nov. Replaced synonym: Senecio subsect. Amplectentes Cabrera, Lilloa 15: 355. 1949, nom. illeg. non Senecio sect. Amplectentes Greenman, 1902. Senecio subser. Amplectentes (Cabrera) Cabrera \& S. E. Freire, Fl. Fanerog. Argent. 62: 22. 1999. TYPE: Senecio hieracium J. Rémy (designated by Cabrera, 1949: 355).

Observations. Subseries Alcabrerae in Senecio sect. Senecio ser. Corymbosi has been circumscribed, recognizing five species from Chile (Cabrera, 1949) and Argentina (Cabrera et al., 1999): S. hieracium, S. saucensis Cabrera, S. prenanthifolius Phil., S. nigrescens Hook. \& Arn., and S. scopulorum Poepp. Senecio toroanus Cabrera may be added to this list as a new synonym for $S$. saucensis. The synonymy with the taxonomic transfer of series is provided below.

\section{Synonymy of SENECIO SAUCENSIS With S. TOROANUS}

Senecio ser. Hualtatini was described by de Candolle (1838: 417) to include robust perennial herbs, from high to giant forms with fistulose stems. The fleshy, basal leaves are largely petiolate, forming a rosette, and the upper leaves are semiamplexicaul. The majority of these characteristics are not present in S. toroanus, which was included in series Hualtatini (Cabrera et al., 1999) on the basis of the inflorescence that is a corymbiform cyme and the presence of ray florets. However, S. toroanus differs from other taxa in series Hualtatini in being only $50 \mathrm{~cm}$ tall, lacking both fistulose stems and fleshy leaves, not forming rosettes, having leafy stems, and having leaves that are small, thin, and irregular in shape. These features support the exclusion of this species from series Hualtatini.

Recent investigation of the micromorphological ornamentation of fruits of the Argentine representatives of Senecio ser. Hualtatini (López, 2005) showed that the series is defined by glabrous cypselae. Senecio toroanus, however, displays pubescent and papillate fruits, which further supports that the species has been placed in series Hualtatini erroneously. Further research by us in Senecio ser. Corymbosi, with comparison with series Hualtatini, reveals morphological and micromorphological similarities between S. toroanus and S. saucensis, which belongs to Senecio ser. Corymbosi subser. Alcabrerae. Analysis of the relevant type specimens (Fig. 1) and the evaluation of the cypsela micromorphology (Fig. 2) confirm that the names are conspecific; hence, the formal proposal is indicated below. As a 


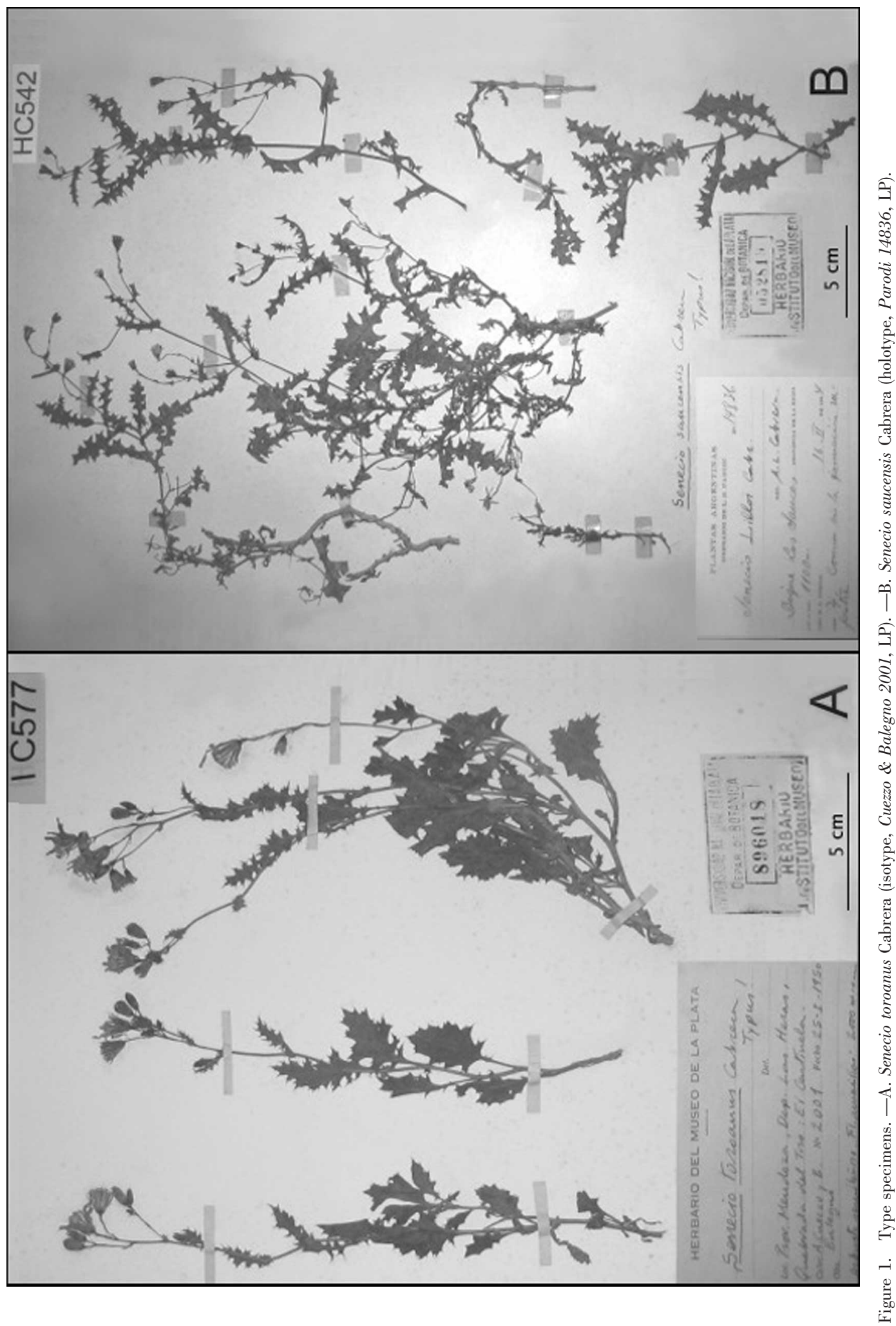



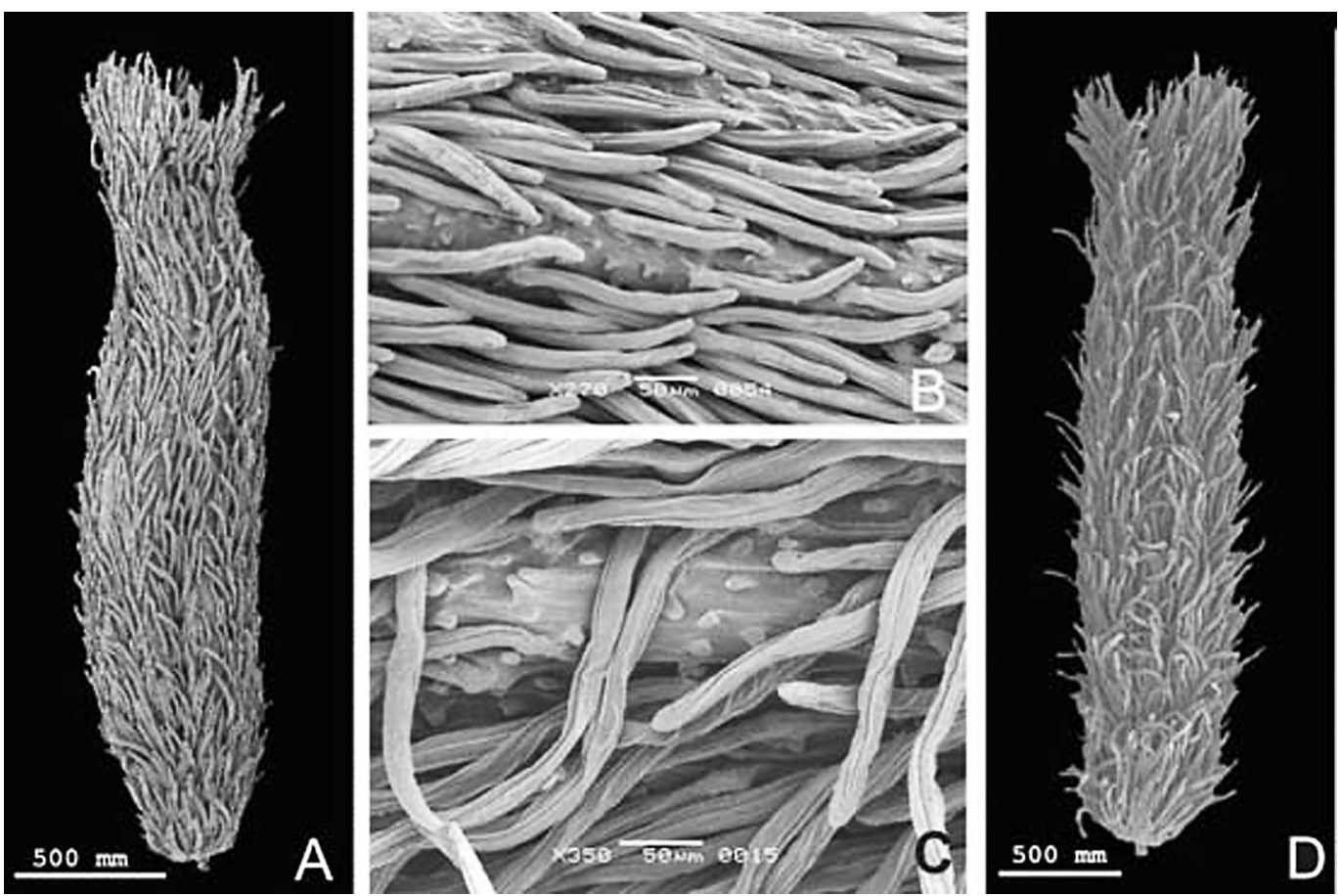

Figure 2. SEM fruit micromorphology. A, B. Senecio saucensis. - A. Pubescent cypsela (Argentina, Prov. Catamarca, Tinogasta, F. A. Roig 15427, SI). - B. Ornamentation of pubescent cypselar surface with papillae also evident (Argentina, Prov. La Rioja, Dept. Capital, Dique Los Sauces, A. Burkart 12627, LP). C, D. Senecio toroanus (Argentina, Prov. Mendoza, Dept. Las Heras, Quebrada del Toro, G. Covas 18570, SI). —C. Pubescent cypsela. —D. Surface ornamentation.

consequence of this taxonomic synonymy, the geographic distribution of $S$. toroanus is extended, with its distributional range in the Argentine mountains of Catamarca, La Rioja, San Juan, and Mendoza provinces, between 2000 and $2700 \mathrm{~m}$ in altitude.

Senecio toroanus Cabrera, Darwiniana 10(4): 573, fig. 11. 1954. TYPE: Argentina. Mendoza: Dept. Las Heras, Quebrada del Toro, El Centinela, 2000 m, 21 Jan. 1950, A. Cuezzo \& B. Balegno 2001 (holotype, LIL not seen; isotype, LP). Figure 1A.

Senecio saucensis Cabrera, Bol. Soc. Argent. Bot. 11(1): 53, fig. 5. 1966, syn. nov. TYPE: Argentina. La Rioja: Dept. Capital, Dique Los Sauces, 16 Feb. 1944, L. Parodi 14836 (holotype, LP). Figure 1B.

Acknowledgments. The authors thank Rafael Urréjola for the SEM photographs, graphic designer Marcelo Girardi, and the curators of LP and SI for their technical assistance. We are grateful to Debra Trock and an anonymous reviewer for comments that improved the manuscript. C.C.X. acknowledges personal support from CIC-PBA.

\section{Literature Cited}

Barkley, T. M. 1985. Infrageneric groups in Senecio s.l. and Cacalia s.l. (Asteraceae: Senecioneae) in Mexico and Central America. Brittonia 37(2): 211-218.

—. 2006. Senecio. Pp. 540-567 in Flora of North America Editorial Committee (editors), Flora of North America North of Mexico, Vol. 20. Oxford University Press, New York.

Cabrera, A. L. 1939. Las especies tucumanas del género Senecio (Compositae). Lilloa 5: 65-120.

- 1949. El género Senecio en Chile. Lilloa 15: $27-501$.

1985. El género Senecio (Compositae) en Bolivia. Darwiniana 26: 79-217.

, S. E. Freire \& L. Ariza Espinar. 1999. Senecio Tribu VIII. Senecioneae. Pp. 12-158 in A. T. Hunziker (editor), Flora Fanerogámica Argentina, Vol. 62. Museo Botánico de Córdoba, Córdoba.

Candolle, A. P. de. 1838. Prodromus Systematis Naturalis Regni Vegetabilis, Vol 6. Truettel and Würtz, Paris.

Gray, A. 1862. Enumeration of the plants. Amer. J. Sci. Arts, ser. 2 33(98): 240.

Greenman, J. M. 1902. Monographie der nord- und centralamerikanischen Arten der Gattung Senecio. Bot. Jahrb. Syst. 32: 1-33.

1915. Monograph of the North and Central American species of the genus Senecio, part II. Ann. Missouri Bot. Gard. 2: 573-626. 
Jeffrey, C. 1988. The tribe Senecioneae (Compositae) in the Mascarene Islands with an annotated world check-list of the genera of the tribe. Notes on Compositae: VI. Kew Bull. 47: 49-109.

López, M. G. 2005. Estudios morfológicos, citotaxonómicos y anatómicos en Senecio sect. Senecio serie Hualtatini. Bol. Soc. Argent. Bot. 40(suppl.): 69.

2008. Estudios Citogenéticos, Evolutivos y Biosistemáticos en Senecio sect. Senecio serie Corymbosi, de Argentina. PhD Thesis, Facultad de Ciencias Exactas y Naturales, Universidad de Buenos Aires, Buenos Aires.

, A. F. Wulff, L. Poggio \& C. C. Xifreda. 2005. Chromosome numbers and meiotic studies in species of
Senecio (Asteraceae) from Argentina. Bot. J. Linn. Soc. 148: $465-474$.

$\longrightarrow,-$ — - . 2008. South African fireweed Senecio madagascariensis (Asteraceae) in Argentina: Relevance of chromosome studies to its systematics. Bot. J. Linn. Soc. 158: 613-620.

McNeill, J., F. R. Barrie, H. M. Burdet, V. Demoulin, D. L. Hawksworth, K. Marhold, D. H. Nicolson, J. Prado, P. C. Silva, J. E. Skog, J. H. Wiersema \& N. J. Turland (editors). 2006. International Code of Botanical Nomenclature (Vienna Code). Regnum Veg. 146.

Ornduff, R., T. Mosquin, D. W. Kyhos \& P. H. Raven. 1967. Chromosome numbers in Compositae VI, Senecioneae II. Amer. J. Bot. 54: 205-213. 